\title{
Pengaruh Kualitas Produk, Harga, Cita Rasa Dan Promosi Terhadap Kepuasan Konsumen Di Rumah Makan Mbak Siti \\ Amir Hamzah Siregar ${ }^{1}$, Susana $^{2}$, Zuriani Ritonga ${ }^{3}$, Desmawati Hasibuan ${ }^{4}$, Elvina ${ }^{5}$ \\ 1,2,3,4,5 Universitas Labuhanbatu, Indonesia
}

Corresponding Author: $\otimes$ amirhamzah@gmail.com

\begin{tabular}{|c|c|}
\hline & ABSTRACT \\
\hline & $\begin{array}{l}\text { The purpose of this study was to determine the effect of product quality, } \\
\text { price, taste and promotion on consumer satisfaction at Mbak Siti's } \\
\text { restaurant in Sosopan Village, Kotapinang District, Labuhanbatu Selatan } \\
\text { Regency. The sample in this study amounted to } 30 \text { people. The analytical } \\
\text { method used is descriptive analysis, classical assumption test, multiple } \\
\text { linear regression analysis, t test, f test, and coefficient of determination and } \\
\text { this data is processed using the IBMSPSS Statistics } 21 \text { program. Hypothesis } \\
\text { test results show that partially the product (X1) has a positive and } \\
\text { significant effect on consumer satisfaction, this can be seen from the tcount } \\
\text { value for product quality is tcount } 0.009>\text { ttable } 2.05954 \text {, with a significant } \\
\text { value of } 0.993<0.05 \text {. Hagra }(X 2) \text { has a positive and significant effect on } \\
\text { consumer satisfaction, this can be seen from the tcount value for price is } \\
\text { tcount } 2.273>\text { ttable } 2.05954 \text {, with a significant value of } 0.32<0.05 \text {. Taste (X3) } \\
\text { has a positive and significant effect on consumer satisfaction, this can be } \\
\text { seen from the tcount value for taste is tcount } 0.541>\text { ttable } 2.05954 \text {, with a } \\
\text { significant value of } 0.593<0.05 \text {. Promotion }(X 4) \text { has a positive and } \\
\text { significant effect on customer satisfaction, this can be seen from the tcount } \\
\text { value for promotion is tcount } 6.794>\text { ttable } 2.05954 \text {, with a significant value } \\
\text { of } 0.000<0.05 \text {. The value of Ftable in the } 4: 26 \text { distribution is } 2.74 \text {, so based } \\
\text { on table } 4.14 \text { it can be seen that the Fcount value is } 36.656>2.70 \text {, and a } \\
\text { significant value is } 0.000<0.05 \text {, this shows that simultaneously the } \\
\text { Independent Variable has a positive and significant effect on the Dependent } \\
\text { Variable. }\end{array}$ \\
\hline Keywords & Price, Taste, Promotion, Customer Satisfaction \\
\hline
\end{tabular}

\section{PENDAHULUAN}

Pertumbuhan usaha kuliner di era global seperti saat ini semakin meningkat sehingga pebisnis dituntut untuk selalu melakukan inovasi-inovasi atau cara-cara yang dapat menarik konsumen agar para pebisnis dapat bersaing dengan pesaing-pesaingnya. Pebisnis dituntut kreatif dalam mengembangkan usahanya agar dapat menarik selera konsumen untuk mencoba produk-produk yang ditawarkan pebisnis. Rumah makan merupakan bisnis yang banyak diminati oleh masyarakat, karena menghasilkan keuntungan yang tinggi. kondisi persaingan pasar saat ini membuat konsumen rentan untuk berubah-ubah. Hal ini disebabkan semakin ketatnya persaingan sehingga setiap 
Journal Economy And Currency Study (JECS)

Volume 3, Issue 1, January 2021

Page 22-33

pebisnis rumah makan dituntut perubahan seperti ; perubahan cara pikir, termasuk dalam pemasaran, dimana sebelumnya hanya fokus ke target penjualan tercapai menjadi lebih kepada menarik konsumen dan tetap berhubungan baik dengan konsumen. Rumah makan MBAK SITI merupakan rumah makan yang sudah ada sejak tahun 2006. Rumah makan MBAK SITI kurang dikenal oleh calon konsumen yang berada diluar daerah. Padahal, Rumah makan MBAK SITI ini sudah termasuk rumah makan yang secara umum mampu bersaing di pasar bisnis. Namun, Jika diamati dari kondisi pesaing disekitarnya, rumah makan MBAK SITI memiliki beberapa keunggulan seperti, tempat parkir yang luas, suasana dalam rumah makan yang nyaman, cita rasa yang khas dan harga yang terjangkau. Fakta menunjukkan bahwa harga untuk satu porsi makan dihargai sebesar Rp.15.000. Dalam sehari rata-rata porsi yang dibeli adalah 30-40 porsi makan dengan omset sebesar Rp.650.000.

Produk merupakan barang yang dikonsumsi oleh konsumen baik jasa maupun industri, produk yang baik harus memiliki keunggulan dibandingkan dari produkproduk yang ada dipasaran, baik dari kualitas, rasa, isian garansi agar produk yang dikeluarkan oleh perusahaan dapat diterima dan diminati konsumen (Sudarsono, 2020) Djaslim Saladin mendefinisikan produk secara singkat bahwa : Produk berupa sekelompok sifat yang berwujud didalamnya sudah mencangkup warna produk, harga, kemasan produk, prestise pengecer dan servis yang diberikan oleh si produsen dan distributor/pengecer yang dapat diterima oleh konsumen sebagai kepuasan yang ditawarkan terhadap minat atau kebutuhan-kebutuhan konsumen. (Wahyudi, 2019). Menurut (Anggraeni \& Kumadji, 2016), kualitas produk merupakan kemampuan suatu produk dalam menjalankan fungsinya, itu termasuk daya tahan beberapa produk, keandalan, presisi, kemudahan pengoperasian dan perbaikan, dan atribut berharga lainnya.

(Fernandito, 2019) “ Pengaruh Kualitas Produk Dan Pelayanan Terhadap Kepuasan konsumen Users Modem Smartfren Pada Mahasiswa FE Universitas Medan Area "Hasil penelitian yang diperoleh yaitu secara parsial variabel kualitas produk memiliki pengaruh positif dansignifikan terhadap variabel kepuasan konsumen dengan nilai variabel kualitas produk yaitu (thitung>ttabel) sedangkan variabel kualitas pelayanan tidak berpengaruh signifikan terhadap variabel kepuasan konsumen dengan nilai variabel kualitas pelayanan berpengaruh positif dansignifikan terhadap kepuasam konsumen dengan nilai (Fhitung>Ftabel).

(Kurniasari \& Santoso, 2013) “Analisis Pengaruh Harga, Kualitas Produk, dan Kualitas Pelayanan Terhadap Keputusan Pembelian (Studi Kasus Pada Konsumen Warung Steak and Shake Cabang Jl.Swrijaya 11 Semarang)" Hasil penelitian menunjukkan bahwa harga, kualitas produk, kualitas pelayanan memiliki pengaruh 
Journal Economy And Currency Study (JECS)

Volume 3, Issue 1, January 2021

Page 22-33

yang positif terhadap keputusan pembelian. Berdasarkan analisis statistik, indikator indikator pada penelitian ini bersifat valid dan variabelnya bersifat reliabel. Pada uji asumsi klasik, model regresi bebas multikolonieritas, tidak terjadi heteroskeditas dan berdistribusi normal. Urutan secara individu dari masingmasing variabel yang paling berpengaruh adalah variabel kualitas produk lalu kualitas pelayanan sedangkan variabel yang paling berpengaruh paling rendah adalah harga.

(Tampubolon, 2015) "Pengaruh Kualitas Pelayanan Terhadap Kepuasan Wisatawan Hillpark Sibolangit"Hasil penelitian menunjukkan bahwa variabel kualitas pelayananan yaitu Bukti fisik (X1) mempunyai pengaruh yang positif sebesar 4,260 terhadap kepuasan konsumen dengan tingkat signifikan sebesar 0,000. Keandalan (X2) mempunyai pengaruh yang positif sebesar 1,380 terhadap kepuasan konsumen dengan tingkat signifikan sebesar 0,011. Ketanggapan (X3) mempunyai pengaruh yang positif sebesar 2,879 terhadap kepuasan konsumen dengan tingkat signifikan sebesar 0,005. Jaminan (X4) mempunyai pengaruh yang positif 5.459 terhadap kepuasan konsumen dengan tingkat signifikan sebesar 0,000 dan Empaty (X5) mempunyai pengaruh yang positif sebesar 1,379 terhadap kepuasan konsumen dengan tingkat signifikan sebesar 0,002 .

Menurut (Julisal, 2016) Harga merupakan sejumlah uang yang dipakai sebagai alat tukar untuk memperoleh produk atau jasa. Menurut (Nuryadin, 2007) harga merupakan satu-satunya dalam bauran pemasaran yang menghasilkan pendapatan, sifatnya fleksibel, artinya dapat diubah dengan cepat. Produk yang memiliki kuaalitas yang sama tetapi harga yang ditetapkan relatif murah akan memberikan value yang lebih tinggi kepada konsumennya, jelas bahwa faktor harga juga merupakan faktor yang penting bagi konsumen untuk mengevaluasi tingkat kepuasanya.

Menurut (Justitie et al., 2020) cita rasa adalah bentuk kerja sama kelima indra yaitu penglihatan, pendengaran, perasa, penciuman dan peraba. (Wulandari \& Susanto, 2020) mendefinisikan bahwa cita rasa adalah cara pemilihan makanan yang harus dibedakan dari rasa (tasted) makanan tersebut. Umumnya pengolah makanan akan berusaha untuk menghasilkan produk yang berkualitas terbaik. Kualitas makanan mencakup atribut dari makanan tersebut yang akan berpengaruh terhadap konsumen.

(Lingga, 2016) Promosi merupakan kegiatan akhir dari marketing mix yang sangat penting karena kebanyakan pasar lebih banyak bersifat pasar pembeli dimana keputusan terakhir terjadinya transaksi jual beli sangat dipengaruhi oleh konsumen. Menurut (Lestari, 2019), Promosi adalah salah satu prioritas dari kegiatan pemasaran yang diberitahukan kepada konsumen bahwa perusahaan meluncurkan produk baru yang menggoda konsumen untuk melakukan kegiatan pembelian. 
Journal Economy And Currency Study (JECS)

Volume 3, Issue 1, January 2021

Page 22-33

\section{Teori Kepuasan Konsumen}

Menurut (Krisdianti \& Sunarti, 2019) yang di kutip dari jurnal Administrasi Bisnis Kepuasan Konsumen adalah perasaan senang atau kecewa seseorang yang muncul setelah membandingkan kinerja (hasil) produk yang dipikirkan terhadap kinerja yang diharapkan. (Krisdianti \& Sunarti, 2019) Kepuasan merupakan tingkat perasaan seseorang setelah membandingkan kinerja atau hasil yang ia rasakan dengan harapannya. Umumnya konsumen berharap tentang apa yang akan ia terima dan konsumsi (baik produk barang atau jasa) sesuai dengan apa yang ia mau, Sedangkan kinerja yang dirasakan adalah persepsi konsumen terhadap apa yang ia terima setelah mengkonsumsi produk yang ia beli.

\section{METODE PENELITIAN}

Pada penelitian ini menggunakan pendekatan data kualitatif yaitu pendekatan yang observasi langsung ke lapangan, dan menggunakan pendekatan kuantitatif yaitu dengan menyebarkan kuisioner. Dengan penelitian ini diharapkan dapat diketahui variabel bebas yaitu Kualitas Produk, Harga, Cita Rasa, Promosi terhadap variabel terikat yaitu Kepuasan Konsumen Rumah Makan Mbak Siti di desa Sosopan kecamatan Kotapinang Kabupaten Labuhanbatu Selatan. Penelitian ini mengambil tempat di Rumah Makan Mbak Siti di desa Sosopan kecamatan Kotapinang Kabupaten Labuhanbatu Selatan. Waktu penelitian diestimasikan memakan waktu 4 bulan hingga penelitian selesai, mulai dari proses melengkapi data, observasi lapangan, hingga proses pengisian kuisioner. Populasi yang diambil dalam penelitian ini adalah para konsumen yang datang pada Rumah Makan Mbak Siti di desa Sosopan kecamatan Kotapinang Kabupaten Labuhanbatu Selatan. Sampel adalah sebagian jumlah dan karakteristik yang dimiliki oleh populasi tersebut bila populasi besar, peneliti tidak mungkin mempelajari semua yang ada pada populasi, misalnya karena keterbatasan dana, tenaga, dan waktu, maka peneliti dapat menggunakan sampel yang diambil dari populasi itu (Usman \& Akbar, 2008), sehingga Jumlah sampel penelitian adalah 30 orang.

\section{HASIL PENELITIAN DAN PEMBAHASAN}

\section{Analisis Regresi Linear Berganda}

Analisis Regresi Linear Berganda diginakan untuk mengetahui seberapa besar antara variabel independent (bebas) terhadap variabel dependent (terikat). Untuk memperoleh hasil pada penelitian ini, digunakan software IBM Statistic SPSS 26. Maka dapat dihasilkan output sebagai berikut : 
Journal Economy And Currency Study (JECS)

Volume 3, Issue 1, January 2021

Page 22-33

Tabel 4.13 Hasil Analisis Regresi Berganda

Coefficients ${ }^{a}$

\begin{tabular}{|c|c|c|c|c|c|c|}
\hline \multirow{2}{*}{\multicolumn{2}{|c|}{ Model }} & \multicolumn{2}{|c|}{$\begin{array}{l}\text { Unstandardized } \\
\text { Coefficients }\end{array}$} & \multirow{2}{*}{$\begin{array}{c}\text { Standardized } \\
\text { Coefficients } \\
\text { Beta }\end{array}$} & \multirow[b]{2}{*}{$\mathrm{t}$} & \multirow[b]{2}{*}{ Sig. } \\
\hline & & B & Std. Error & & & \\
\hline \multirow[t]{5}{*}{1} & (Constant) & 3.044 & 2.428 & & 1.254 & .222 \\
\hline & Total_X1 & .001 & .087 & .001 & .009 & .993 \\
\hline & Total_X2 & .150 & .066 & .277 & 2.273 & .032 \\
\hline & Total_X3 & .063 & .116 & .060 & .541 & .593 \\
\hline & Total_X4 & .620 & .091 & .684 & 6.794 & .000 \\
\hline
\end{tabular}

a. Dependent Variable: Total_Y1

Berdasarkan Tabel 4.11 maka dapat dibuat persamaan yaitu :

$\mathrm{Y}=3,044+0,001+0,150+0,063+0,620$

Koefisien Regresi Kualitas Produk (X1) menunjukkan Hubungan Positif terhadap Kepuasan Konsumen dengan Nilai Koefisien sebesar 0,001. Berarti setiap peningkatan Kualitas Produk (X1) sebesar 0,001 akan meningkatkan Kepuasan Konsumen sebesar 0,001. Koefisien Regresi Harga (X2) menunjukkan hubungan positif terhadap Kepuasan Konsumen dengan Nilai Koefisien sebesar 0,150. Berarti setiap Peningkatan Harga (X2) sebesar 0,150 akan meningkatkan Kepuasan Konsumen sebesar 0,150. Koefisien Regresi Cita Rasa (X3) menunjukkan Hubungan Positif terhadap Kepuasan Konsumen dengan Nilai Koefisien sebesar 0,063. Berarti setiap Peningkatan Cita Rasa (X3) sebesar 0,063 akan meningkatkan Kepuasan Konsumen sebesar 0,063. Koefisien Regres Promosi menunjukkan hubungan positif terhadap Kepuasan Konsumen dengan Nilai Koefisien sebesar 0,620. Berarti setiap Peningkatan Promosi sebesar 0,620 akan meningkatkan Kepuasan Konsumen sebesar 0,620. Nilai Konstanta sebesar 3,044 menunjukkan bahwa Kepuasan Konsumen sebesar 3,044 dengan adanya pengaruh dari Kualitas Produk, Harga, Cita Rasa, dan Promosi.

Uji Parsial (Uji T)

Pengujian ini dilakukan dengan membandingkan antara $t$ tabel dengan $t_{\text {hitung. }}$ Diketahui $\mathrm{T}$ tabel pada distribusi $\alpha: 0,05$ maka $\mathrm{t}_{\text {tabel }}$ dapat dicari dengan rumus $\left(\mathrm{t}_{\text {tabel }}=\mathrm{t}(\mathrm{\alpha} / 2 ; \mathrm{n}-\mathrm{k}-1)\right.$ $=\mathrm{t}(0,025 ; 25)$ adalah 2.05954 . Uji T ini dilakukan untuk mengetahui pengaruh masingmasing variabel bebas terhadap variabel terikat, Hasil Uji T dapat dilihat 4.13 dibawah ini : 
Journal Economy And Currency Study (JECS)

Volume 3, Issue 1, January 2021

Page 22-33

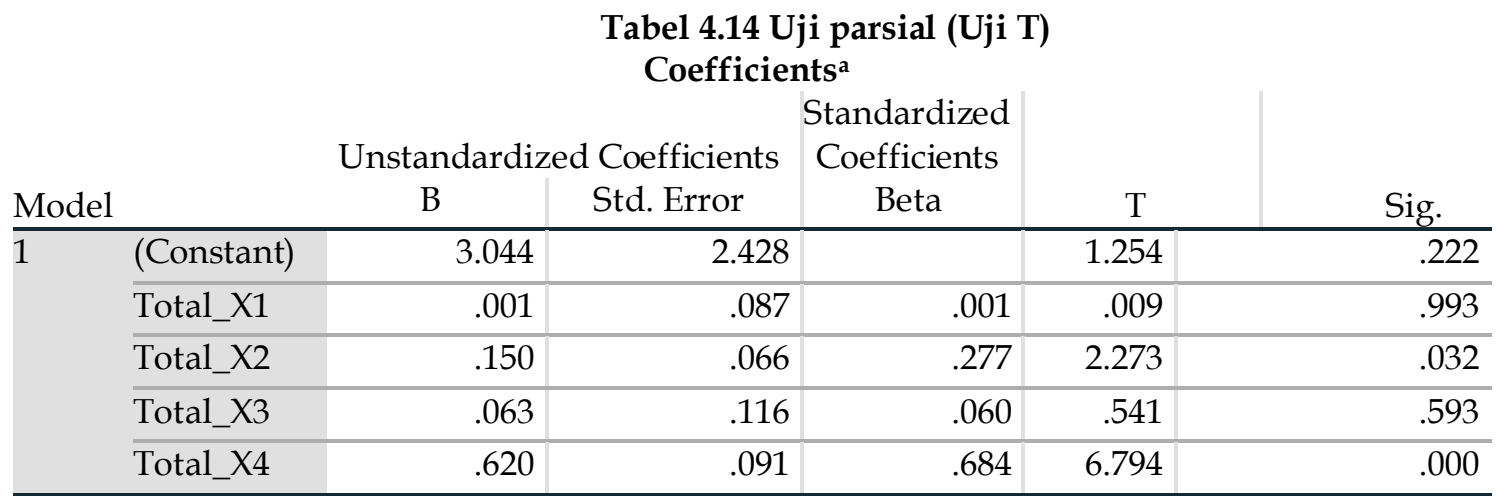

a. Dependent Variable: Total_Y1

Berdasarkan Kriteria diatas bahwa jika niai $t_{\text {hitung }}>t_{\text {tabel }}$ maka variabel berpengaruh Positif dan Signifikan, dapat dilihat hasil output SPSS Uji T sebagai berikut

1. Berdasarkan Output SPSS di atas diketahui nilai Sig untuk pengaruh variabel Kualitas Produk (X1) terhadap Kepuasan konsumen (Y) adalah sebesar 0,993 > 0,05 dan nilai thitung $0,009<2.05954$, sehingga dapat disimpulkan bahwa H1 ditolak yang berarti tidak terdapat pengaruh X1 terhadap Y.

2. Berdasarkan Output SPSS di atas diketahui nilai Sig untuk pengaruh variabel Harga (X2) terhadap Kepuasan konsumen (Y) adalah sebesar 0,032 > 0,05 dan nilai thitung $2,273<2.05954$, sehingga dapat disimpulkan bahwa H2 diterima yang berarti terdapat pengaruh $\mathrm{X} 2$ terhadap $\mathrm{Y}$.

3. Berdasarkan Output SPSS di atas diketahui nilai Sig untuk pengaruh variabel Cita Rasa (X3) terhadap Kepuasan konsumen (Y) adalah sebesar 0,593 > 0,05 dan nilai thitung $0,541<2.05954$, sehingga dapat disimpulkan bahwa H3 ditolak yang berarti tidak terdapat pengaruh X3 terhadap $\mathrm{Y}$.

4. Berdasarkan Output SPSS di atas diketahui nilai Sig untuk pengaruh variabel Promosi (X4) terhadap Kepuasan konsumen (Y) adalah sebesar 0,000 > 0,05 dan nilai thitung 6,794<2,05954, sehingga dapat disimpulkan bahwa H4 diterima yang berarti terdapat pengaruh $\mathrm{X} 4$ terhadap $\mathrm{Y}$.

5. Berdasarkan Hasil di atas diketahui jika nilai $t_{\text {hitung }}>t_{\text {tabel }}$ variabel Kualitas Produk (X1) $(0,009>2,05954)$, variabel Harga (X2) $(2,273>2,05954)$, variabel Cita Rasa (X3) $(0,541>2,05954)$ dan variabel Promosi (X4) (6,794 > 2,05954). Maka dapat disimpulkan bahwa Variabel Kualitas Produk (X1), Cita Rasa (X3) tidak berpengaruh signifikan terhadap Kepuasan Konsumen (Y) tetapi Harga (X2), dan Promosi (X4) berpengaruh Positif dan Signifikan terhadap Keputusan Penggunaan $(\mathrm{Y})$. 
Journal Economy And Currency Study (JECS)

Volume 3, Issue 1, January 2021

Page 22-33

Uji F dilakukan untuk menguji secara simultan (secara bersama-sama) apakah Kualitas Produk $\left(X_{1}\right)$, Harga $\left(X_{2}\right)$, Cita Rasa $\left(X_{3}\right)$ dan Promosi $\left(X_{4}\right)$ berpengaruh positif dan signifikan terhadap Kepuasan Konsumen (Y) pada Rumah Makan Mbak Siti.

\begin{tabular}{|c|c|c|c|c|c|c|}
\hline \multicolumn{7}{|c|}{$\begin{array}{c}\text { Tabel } 4.15 \text { Uji Simultan F } \\
\text { ANOVA }^{\mathrm{a}}\end{array}$} \\
\hline & Model & Sum of Squares & Df & Mean Square & $\mathrm{F}$ & Sig. \\
\hline \multirow[t]{3}{*}{1} & Regression & 133.162 & 4 & 33.290 & 36.656 & $.000^{\mathrm{b}}$ \\
\hline & Residual & 22.705 & 25 & .908 & & \\
\hline & Total & 155.867 & 29 & & & \\
\hline
\end{tabular}

Berdasarkan rumus $\mathrm{F}_{\text {tabel }}$ maka $\left(\mathrm{F}_{\text {tabel }}=\mathrm{F}(\mathrm{k} ; \mathrm{n}-\mathrm{k})=\mathrm{F}(4 ; 26)=2,74\right)$. Maka berdasarkan tabel 4.14 terlihat bahwa nilai $F_{\text {hitung }} 36,656>2,74$ dan nilai signifikan 0,000 $<0,05$ ini menunjukkan bahwa sekumpulan Variabel Independent berpengaruh Positif dan Signifikan terhadap Variabel Dependent.

\section{Koefisien Determinasi}

Koefisien Determinan $\left(R^{2}\right)$ digunakan mengukur seberapa jauh kemampuan Variabel Independent dalam mempengaruhi Variabel Dependen. Nilai Koefisien Determinasi dapat dilihat pada tabel di bawah ini :

Tabel 4.16 Koefisien Determinasi $\left(\mathbf{R}^{2}\right)$ Model Summaryb

\begin{tabular}{l|r|rrr} 
Model & $\mathrm{R}$ & R Square & $\begin{array}{l}\text { Adjusted R } \\
\text { Square }\end{array}$ & $\begin{array}{l}\text { Std. Error of } \\
\text { the Estimate }\end{array}$ \\
\hline 1 & $.924^{\mathrm{a}}$ & .854 & .831 & .953 \\
\hline $\begin{array}{l}\text { a. Predictors: (Constant), Total_X4, Total_X1, Total_X3, Total_X2 } \\
\text { b. Dependent Variable: Total_Y1 }\end{array}$
\end{tabular}

Berdasarkan Output SPSS di atas diketahui nilai R Square sebesar 0,854, hal ini mengandung arti bahwa pengaruh Variabel $\mathrm{X}_{1}, \mathrm{X}_{2}, \mathrm{X}_{3}$ dan $\mathrm{X}_{4}$ secara simultan terhadap Variabel $Y$ adalah sebesar 85,4\%.

\section{H1 - Kualitas Produk $\left(X_{1}\right)$ berpengaruh Positif dan Signifikan terhadap Kepuasan Konsumen (Y) pada Rumah Makan Mbak Siti Kotapinang}

Garis Regresi Linear Berganda menunjukkan bahwa tingkat perubahan Variabel Y adalah perubahan Positif, jadi dapat disimpulkan bahwa Variabel Independent memberikan kontribusi yang Positif terhadap Variabel Y. Diperoleh Garis Regresi Linear Berganda: 
Journal Economy And Currency Study (JECS)

Volume 3, Issue 1, January 2021

Page 22-33

$$
Y=3,044+0,001+0,150+0,063+0,620
$$

Koefisien Regresi Kualitas Produk (X1) menunjukkan hubungan Positif terhadap Keputusan Penggunaan dengan Nilai Koefisien sebesar 0,001. Berarti setiap peningkatan Variabel Kualitas Produk (X1) sebesar 0,001 akan meningkatkan Kepuasan Konsumen (Y) sebesar 0,001.

Berdasarkan Output SPSS di atas diketahui nilai variabel Kualitas Produk (X1) adalah $t_{\text {hitung }} 0,009>t_{\text {tabel }} 2,05954$ dengan nilai signifikan 0,993 $<0,05$. Maka dapat disimpulkan bahwa Ho diterima dan Ha ditolak. Kualitas Produk (X1) berpengaruh Positif dan Signifikan terhadap Kepuasan Konsumen (Y).

\section{H2 - Harga (X2) berpengaruh Positif dan Signifikan terhadap Kepuasan Konsumen (Y) pada Rumah Makan Mbak Siti Kotapinang}

Garis Regresi Linear Berganda menunjukkan bahwa tingkat perubahan Variabel Y adalah perubahan Positif, jadi dapat disimpulkan bahwa Variabel Independent memberikan kontribusi yang Positif terhadap Variabel Y. Diperoleh Garis Regresi Linear Berganda:

$$
\mathrm{Y}=3,044+0,001+0,150+0,063+0,620
$$

Koefisien Regresi Harga (X2) menunjukkan hubungan Positif terhadap Kepuasan Konsumen dengan Nilai Koefisien sebesar 0,150. Berarti setiap peningkatan Variabel Harga (X2) sebesar 0,150 akan meningkatkan Kepuasan Konsumen (Y) sebesar 0,150.

Berdasarkan Output SPSS di atas diketahui nilai variabel Harga (X2) adalah $t_{\text {hitung }}$ $2,273>t_{\text {tabel }} 2,05954$, dengan nilai signifikan $0,032<0,05$. Maka dapat disimpulkan bahwa Ho ditolak dan Ha diterima. Harga (X2) berpengaruh Negatif dan Signifikan terhadap Kepuasan Konsumen (Y).

\section{H3 - Cita Rasa (X3) berpengaruh Positif dan Signifikan terhadap Kepuasan Konsumen (Y) pada Rumah Makan Mbak Siti Kotapinang}

Garis Regresi Linear Berganda menunjukkan bahwa tingkat perubahan Variabel Y adalah perubahan Positif, jadi dapat disimpulkan bahwa Variabel Independent memberikan kontribusi yang Positif terhadap Variabel Y. Diperoleh Garis Regresi Linear Berganda:

$$
\mathrm{Y}=3,044+0,001+0,150+0,063+0,620
$$

Koefisien Regresi Cita Rasa (X3) menunjukkan hubungan Positif terhadap Kepuasan Konsumen dengan Nilai Koefisien sebesar 0,063. Berarti setiap peningkatan 
Journal Economy And Currency Study (JECS)

Volume 3, Issue 1, January 2021

Page 22-33

Variabel Cita Rasa (X3) sebesar 0,063 akan meningkatkan Kepuasan Konsumen (Y) sebesar 0,063.

Berdasarkan Output SPSS di atas diketahui nilai variabel Cita Rasa (X3) adalah $t_{\text {thitung }} 0,541>t_{\text {tabel }} 2,05954$, dengan nilai signifikan 0,593 $<0,05$. Maka dapat disimpulkan bahwa Ho diterima dan Ha ditolak. Cita Rasa (X3) berpengaruh Positif dan Signifikan terhadap Kepuasan Konsumen (Y).

\section{H4 - Promosi (X4) berpengaruh Positif dan Signifikan terhadap Kepuasan Konsumen (Y) pada Rumah Makan Mbak Siti Kotapinang}

Garis Regresi Linear Berganda menunjukkan bahwa tingkat perubahan Variabel Y adalah perubahan Positif, jadi dapat disimpulkan bahwa Variabel Independent memberikan kontribusi yang Positif terhadap Variabel Y. Diperoleh Garis Regresi Linear Berganda:

$$
\mathrm{Y}=3,044+0,001+0,150+0,063+0,620
$$

Koefisien Regresi Promosi (X4) menunjukkan hubungan Positif terhadap Kepuasan Konsumen dengan Nilai Koefisien sebesar 0,620. Berarti setiap peningkatan Variabel Promosi (X4) sebesar 0,620 akan meningkatkan Kepuasan Konsumen (Y) sebesar 0,620.

Berdasarkan Output SPSS di atas diketahui nilai variabel Promosi (X4) adalah thitung $6,794>t_{\text {tabel }} 2,05954$, dengan nilai signifikan $0,000<0,05$. Maka dapat disimpulkan bahwa Ho ditolak dan Ha diterima. Promosi (X4) berpengaruh Negatif dan Signifikan terhadap Kepuasan Konsumen (Y).

H5 - Pengaruh Kualitas Produk (X1), Harga (X2), Cita Rasa (X3), dan Promosi (X4) berpengaruh Positif dan Signifikan terhadap Kepuasan Konsumen (Y) pada Rumah Makan Mbak Siti Kotapinang

Dari Hasil Analisis Uji Data diatas diperoleh bahwa hubungan antara Kualitas Produk (X1), Harga (X2), Cita Rasa (X3), dan Promosi (X4) terhadap Kepuasan Konsumen (Y) adalah berkorelasi Positif dan Signifikan, berarti bahwa Kualitas Produk (X1), Harga (X2), Cita Rasa (X3), dan Promosi (X4) dipersepsi baik maka Kepuasan Konsumen (Y) juga akan tinggi.

Nilai Konstanta sebesar 3,044 menunjukkan bahwa Kepuasan Konsumen (Y) Rumah Makan Makan Mbak Siti Kotapinang sebesar 3,044 dengan adanya pengaruh Kualitas Produk (X1), Harga (X2), Cita Rasa (X3), dan Promosi (X4).

Nilai $F_{\text {tabel }}$ pada distribusi $4: 26$ adalah 2,74, maka berdasarkan tabel 4.14 terlihat bahwa nilai Fhitung 36,656 > 2,74, dan Nilai Signifikan 0,000 <0,05, ini menunjukkan bahwa 
Journal Economy And Currency Study (JECS)

Volume 3, Issue 1, January 2021

Page 22-33

secara Simultan Variabel Independent berpengaruh Positif dan Signifikan terhadap Variabel Dependent.

Hasil Output SPSS model summary besarnya R Square adalah 0,854 . Hal ini berarti 85,4\% Variabel Independent memberikan Pengaruh terhadap Variabel Dependent dan sisanya sebesar $14,6 \%$ di Pengaruhi oleh faktor lain yang tidak diteliti.

\section{KESIMPULAN}

Berdasarkan Hasil Penelitian dan Pembahasan yang dilakukan, maka diperoleh Kesimpulan sebagai berikut :

1. Secara Parsial Kualitas Produk (X1) berpengaruh Positif dan Signifikan terhadap Kepuasan Konsumen, hal ini dilihat dari Nilai thitung untuk Kualitas Produk adalah $t_{\text {thitung }} 0,009>t_{\text {tabel }} 2,05954$, dengan nilai signifikan 0,993 $<0,05$. Maka dapat disimpulkan bahwa Ho diterima dan Ha ditolak.

2. Secara Parsial Hagra (X2) berpengaruh Positif dan Signifikan terhadap Kepuasan Konsumen, hal ini dilihat dari Nilai thitung untuk Harga adalah $t_{\text {hitung }} 2,273>t_{\text {tabel }}$ 2,05954, dengan nilai signifikan 0,32 < 0,05. Maka dapat disimpulkan bahwa Ho ditolak dan Ha diterima.

3. Secara Parsial Cita Rasa (X3) berpengaruh Positif dan Signifikan terhadap Kepuasan Konsumen, hal ini dilihat dari Nilai $t_{\text {hitung }}$ untuk Cita Rasa adalah $t_{\text {hitung }} 0,541>t_{\text {tabel }}$ 2,05954, dengan nilai signifikan 0,593 < 0,05. Maka dapat disimpulkan bahwa Ho diterima dan Ha ditolak.

4. Secara Parsial Promosi (X4) berpengaruh Positif dan Signifikan terhadap Kepuasan Konsumen, hal ini dilihat dari Nilai thitung untuk Promosi adalah $t_{\text {hitung }} 6,794>t_{\text {tabel }}$ 2,05954, dengan nilai signifikan 0,000 < 0,05. Maka dapat disimpulkan bahwa Ho ditolak dan Ha diterima.

5. Nilai $\mathrm{F}_{\text {tabel }}$ pada distribusi $4: 26$ adalah 2,74, maka berdasarkan tabel 4.14 terlihat bahwa nilai $F_{h i t u n g} 36,656>2,70$, dan Nilai Signifikan 0,000 <0,05, ini menunjukkan bahwa secara Simultan Variabel Independent berpengaruh Positif dan Signifikan terhadap Variabel Dependent.

6. Hasil Output SPSS model summary besarnya R Square adalah 0,854. Hal ini berarti 85,4\% Variabel Independent memberikan Pengaruh terhadap Variabel Dependent dan sisanya sebesar 14,6\% di Pengaruhi oleh faktor lain yang tidak diteliti.

\section{DAFTAR PUSTAKA}

Anggraeni, D. P., \& Kumadji, S. (2016). Pengaruh Kualitas Produk Terhadap Kepuasan Dan Loyalitas Pelanggan (Survei Pada Pelanggan Nasi Rawon Di Rumah Makan Sakinah Kota Pasuruan). Jurnal Administrasi Bisnis, 37(1), 171-177.

Elvina. (2018). Pengaruh Insentif Dan Kompetensi Terhadap Kinerja Karyawan Pt. Duta 
Journal Economy And Currency Study (JECS)

Volume 3, Issue 1, January 2021

Page 22-33

Expo Labuhanbaturantauprapat. Interciencia, 5(1), 58-65.

Fernandito, M. S. (2019). Pengaruh Kualitas Produk Dan Pelayanan Terhadap Kepuasan Konsumen Pada Pt. Andalan Inovasi Ruangan Medan. Universitas Dharmawangsa.

Harahap, D. A., Hairunnisah, A. I., \& Pitriyani. (2018). Rehabilitation Of Principal In Regional Autonomy (Case Study In Regency Of Labuhanbatu). International Journal Of Scientific And Technology Research, 7(6), 31-33.

Harahap, N. J., \& Rafika, M. (2020). Industrial Revolution 4.0: And The Impact On Human Resources. Ecobisma (Jurnal Ekonomi, Bisnis Dan Manajemen), 7(1), 89-96. Https:/ / Doi.Org/10.36987/Ecobi.V7i1.1545

Julisal, R. I. (2016). Pengaruh Harga Terhadap Loyalitas Pelanggan Pada Cafe "Kupu Bistro" Bandung. Fakultas Ekonomi Dan Bisnis (UNISBA).

Justitie, D., Suddin, A., \& Widajanti, E. (2020). Analisis Pengaruh Kualitas Produk, Cita Rasa, Dan Harga Terhadap Loyalitas Pelanggan Waffelio Franchise Di Surakarta. Jurnal Manajemen Sumber Daya Manusia, 13(2).

Krisdianti, D. L., \& Sunarti, S. (2019). Pengaruh Kualitas Pelayanan Terhadap Kepuasan Konsumen Pada Restoran Pizza Hut Malang Town Square. Jurnal Administrasi Bisnis, 70(1), 36-44.

Kurniasari, N. D., \& Santoso, S. B. (2013). Analisis Pengaruh Harga, Kualitas Produk, Dan Kualitas Pelayanan Terhadap Keputusan Pembelian (Studi Kasus Pada Konsumen Waroeng Steak E Shake Cabang Jl. Sriwijaya 11 Semarang). Fakultas Ekonomika Dan Bisnis.

Lestari, R. (2019). Pengaruh Word Of Mouth Terhadap Keputusan Pembelian Pada Rumah Makan Sambalado Di Setu Cimuning. Parameter, 4(2).

Lingga, G. (2016). Efektifitas Bauran Pemasaran Dalam Meningkatkan Omset Penjualan Pada Rumah Makan Bungo Palo Palembang. Politeknik Negeri Sriwijaya.

Nuryadin, M. B. (2007). Harga Dalam Perspektif Islam. Jurnal Ekonomi Islam: Mazahib, $4(1), 86-98$.

Prayoga, Y. (2019a). Pengaruh Edukasi Dan Sosialisasi Sekolah Pasar Modal Bursa Efek Indonesia Terhadap Motivasi Membeli Saham Di Galeri Investasi Universitas Labuhan Batu. Ecobisma (Jurnal Ekonomi, Bisnis Dan Manajemen), 6(2), 137-144. Http://Jurnal.Ulb.Ac.Id/Index.Php/Ecobisma/Article/View/1401

Prayoga, Y. (2019b). Peranan Industri Batu Bata Terhadap Tingkat Kemiskinan Di

Kecamatan Rantau Selatan Kabupaten Labuhan Batu. Ecobisma (Jurnal Ekonomi, Bisnis Dan Manajemen), 5(2), 47-53. Https:/ /Doi.Org/10.36987/Ecobi.V5i2.55

Ritonga, Z. (2018). Pengaruh Strategi Bersaing Dan Orientasi Wirausaha Terhadap Kinerja Perusahaan Dengan Lingkungan Persaingan Sebagai Variabel Moderator (Studi Pada Perusahaan Jasa Laundry Di Labuhanbatu). Ecobisma (Jurnal Ekonomi, Bisnis Dan Manajemen), 5(2), 107-119. 
Journal Economy And Currency Study (JECS)

Volume 3, Issue 1, January 2021

Page 22-33

Sudarsono, H. (2020). Manajemen Pemasaran. Pustaka Abadi.

Syamsuri, A. R., \& Siregar, Z. M. E. (2019). Organizational Transformation Strategy: Perspective Of Hrm Theory. International Journal Of Scientific And Technology Research, $8(10), 2251-2256$.

Tampubolon, D. (2015). Pengaruh Kualitas Pelayanan, Terhadap Kepuasan Wisatawan Hillpark Sibolangit. Unimed.

Usman, H., \& Akbar, P. S. (2008). Metodologi Penelitian Sosial. Bumi Aksara.

Wahyudi, M. I. (2019). Pengaruh Kualitas Produk, Harga Dan Gaya Hidup Terhadap Keputusan Pembelian (Studi Kasus Di Eiger Store Purwokerto). IAIN Purwokerto.

Wulandari, S., \& Susanto, S. (2020). Keberhasilan Mempertahankan Warung Makan Prasmanan Mbah San. Solusi, 18(1). 